\title{
UNDANG - UNDANG HAKI PADA TEKNOLOGI INFORMASI KOMUNIKASI
}

\author{
Heru Pratama \\ 155100035,785567861 \\ Fakultas Komputer \\ herupratama.student@umitra.ac.id
}

\begin{abstract}
Kekayaan intelektual adalah kekayaan yang timbul dari kemampuan intelektual manusia yang dapat berupa karya di bidang teknologi, ilmu pengetahuan, seni dan sastra. Karya ini dihasilkan atas kemampuan intelektual melalui pemikiran, daya cipta dan rasa yang memerlukan curahan tenaga, waktu dan biaya untuk memperoleh "produk" baru dengan landasan kegiatan penelitian atau yang sejenis.

Secara singkat HAKI adalah hak yang muncul bagi hasil olah pikir otak yang menghasilkan suatu produk atau proses yang berguna bagi manusia .Objek yang diatur dalam HAKI adalah karya-karya yang lahir akibat kemampuan intelektual manusia.

Hak Cipta merupakan hak eksklusif bagi Pencipta atau Pemegang Hak Cipta untuk mengumumkan atau memperbanyak Ciptaannya, yang timbul secara otomatis setelah suatu ciptaan dilahirkan tanpa mengurangi pembatasan menurut peraturan perundang ᄀundangan yang berlaku.

Pencipta dan/atau Pemegang Hak Cipta atas karya sinematografi dan Program Komputer memiliki hak untuk memberikan izin atau melarang orang lain yang tanpa persetujuannya menyewakan Ciptaan tersebut untuk kepentingan yang bersifat komersial.

Pemegang Hak Cipta berhak memberikan Lisensi kepada pihak lain berdasarkan surat perjanjian lisensi. Pelaksanaan perjanjian lisensi tersebut disertai dengan kewajiban pemberian royalti kepada Pemegang Hak Cipta oleh penerima Lisensi. Jumlah royalti yang wajib dibayarkan kepada Pemegang Hak Cipta oleh penerima Lisensi adalah berdasarkan kesepakatan kedua belah pihak dengan berpedoman kepada kesepakatan organisasi profesi.
\end{abstract}

Kata Kunci : HAKI 


\section{A. INTRODUCTION}

Kekayaan intelektual adalah kekayaan yang timbul dari kemampuan intelektual manusia yang dapat berupa karya di bidang teknologi, ilmu pengetahuan, seni dan sastra. Karya ini dihasilkan atas kemampuan intelektual melalui pemikiran, daya cipta dan rasa yang memerlukan curahan tenaga, waktu dan biaya untuk memperoleh "produk" baru dengan landasan kegiatan penelitian atau yang sejenis.

Secara singkat HAKI adalah hak yang muncul bagi hasil olah pikir otak yang menghasilkan suatu produk atau proses yang berguna bagi manusia .Objek yang diatur dalam HAKI adalah karya-karya yang lahir akibat kemampuan intelektual manusia.

Secara umum HAKI dibagi menjadi 2 (dua) bagian, yaitu:

\section{Hak Cipta (copyrights)}

Hak Cipta merupakan hak eksklusif bagi Pencipta atau Pemegang Hak Cipta untuk mengumumkan atau memperbanyak Ciptaannya, yang timbul secara otomatis setelah suatu ciptaan dilahirkan tanpa mengurangi pembatasan menurut peraturan perundang ᄀundangan yang berlaku.

Pencipta dan/atau Pemegang Hak Cipta atas karya sinematografi dan Program Komputer memiliki hak untuk memberikan izin atau melarang orang lain yang tanpa persetujuannya menyewakan Ciptaan tersebut untuk kepentingan yang bersifat komersial.

Ciptaan yang dilindungi oleh Undang-undang adalah Ciptaan dalam bidang ilmu pengetahuan, seni, dan sastra, yang mencakup: a. buku, Program Komputer, pamflet, perwajahan (lay out) karya tulis yang diterbitkan, dan semua hasil karya tulis lain;

b. ceramah, kuliah, pidato, dan Ciptaan lain yang sejenis dengan itu; c. alat peraga yang dibuat untuk kepentingan pendidikan dan ilmu pengetahuan;

d. lagu atau musik dengan atau tanpa teks;

e. drama atau drama musikal, tari, koreografi, pewayangan, dan pantomim;

f. seni rupa dalam segala bentuk seperti seni lukis, gambar, seni ukir, seni kaligrafi, seni pahat, seni patung, kolase, dan seni terapan; g.arsitektur;

hpeta

i.senibatik;

j.photografi

k.sinematografi

1. terjemahan, tafsir, saduran, bunga rampai, database, dan karya lain dari hasil pengaliwujudan.

Pemegang Hak Cipta berhak memberikan Lisensi kepada pihak lain berdasarkan surat perjanjian lisensi. Pelaksanaan perjanjian lisensi tersebut disertai dengan kewajiban pemberian royalti kepada Pemegang Hak Cipta oleh penerima Lisensi. Jumlah royalti yang wajib dibayarkan kepada Pemegang Hak Cipta oleh penerima Lisensi adalah berdasarkan kesepakatan kedua belah pihak dengan berpedoman kepada kesepakatan organisasi profesi.

\section{PELANGGARAN HAK CIPTA :}

dapat dikenakan hukuman sesuai dengan pasal 72 Undang-undang :

(1) Barangsiapa dengan sengaja dan tanpa hak melakukan perbuatan 
sebagaimana dimaksud dalam Pasal 2 ayat (1) atau Pasal 49 ayat (1) dan ayat (2) dipidana dengan pidana penjara masing-masing paling singkat 1 (satu) bulan dan/atau denda paling sedikit Rp 1.000.000,00 (satu juta rupiah), atau pidana penjara paling lama 7 (tujuh) tahun dan/atau denda paling banyak Rp 5.000.000.000,00 (lima miliar rupiah).

(2) Barangsiapa dengan sengaja menyiarkan, memamerkan, mengedarkan, atau menjual kepada umum suatu Ciptaan atau barang hasil pelanggaran Hak Cipta atau Hak Terkait sebagaimana dimaksud pada ayat (1) dipidana dengan pidana penjara paling lama 5 (lima) tahun dan/atau denda paling banyak $\mathrm{Rp}$ 500.000.000,00 (lima ratus juta rupiah).

(3) Barangsiapa dengan sengaja dan tanpa hak memperbanyak penggunaan untuk kepentingan komersial suatu Program Komputer dipidana dengan pidana penjara paling lama 5 (lima) tahun dan/atau denda paling banyak $\mathbf{C}$ Rp 500.000.000,00 (lima ratus juta rupiah).

(4) Barangsiapa dengan sengaja melanggar Pasal 17 dipidana dengan pidana penjara paling lama 5 (lima) tahun dan/atau denda paling banyak Rp 1.000.000.000,00 (satu miliar rupiah).

(5) Barangsiapa dengan sengaja melanggar Pasal 19, Pasal 20, atau Pasal 49 ayat (3) dipidana dengan pidana penjara paling lama 2 (dua) tahun dan/atau denda paling banyak Rp 150.000.000,00 (seratus lima puluh juta rupiah).

(6) Barangsiapa dengan sengaja dan tanpa hak melanggar Pasal 24 atau Pasal 55 dipidana dengan pidana penjara paling lama 2 (dua) tahun dan/atau denda paling banyak $\mathrm{Rp}$ 150.000.000,00 (seratus lima puluh juta rupiah). (7) Barangsiapa dengan sengaja dan tanpa hak melanggar Pasal 25 dipidana dengan pidana penjara paling lama 2 (dua) tahun dan/atau denda paling banyak Rp 150.000.000,00 (seratus lima puluh juta rupiah). (8) Barangsiapa dengan sengaja dan tanpa hak melanggar Pasal 27 dipidana dengan pidana penjara paling lama 2 (dua) tahun dan/atau denda paling banyak Rp 150.000.000,00 (seratus lima puluh juta rupiah). (9) Barangsiapa dengan sengaja melanggar Pasal 28 dipidana dengan pidana penjara paling lama 5 (lima) tahun dan/atau denda paling banyak Rp 1.500.000.000,00 (satu miliar lima ratus juta rupiah).

\section{Hak Kekayaan Industri (industrial property rights)}

\section{Contoh Kasus Pelanggaran HAKI di Bidang TIK}

- Memperbanyak dan atau menjual tanpa seizin pemegang hak cipta. Pelanggaran ini sering kita dengar sebagai pembajakan software dan merupakan pelanggaran paling populer di banyak negara, tentu saja termasuk Indonesia. Namun di beberapa negara ada juga hukum yang melegalkan penjualan untuk kepentingan pendidikan (khususnya bagi software non-edukasi) atau software yang telah dimodifikasi bagi penderita tuna netra.

- Memperbanyak dan memberikannya kepada orang lain. Pelanggaran ini menyalahi banyak undang-undang dari 
hak cipta. Tetapi dalam keadaan khusus bisa jadi tindakan ini tidak termasuk pelanggaran. Misalnya di Israel dan beberapa negara lainnya, memperbanyak suatu karya (termasuk software) tidak melanggar hukum sepanjang dilaksanakan tanpa niat mencari untung.

- Membuat copy sebagai backup data. Pada beberapa negara seperti Jerman, Spanyol, Brazil, Dan Filipina, tindakan ini menjadi hak utama bagi pembeli software. Namun dapat juga menjadi pelanggaran tergantung pada hukum dan keputusan-keputusan hakim terkait kasus yang pernah terjadi di negara yang bersangkutan, yang akhir-akhir ini mengalami banyak perubahan di banyak negara.

- Menyewakan software orisinal kepada orang lain. Lisensi software biasanya membatasi hak pembeli untuk meminjamkan hasil karya yang dilindungi oleh hak cipta. Tetapi beberapa undang-undang masih memperdebatkan tentang larangan tersebut sehingga jalan terbaik dapat dicapai dengan cara meminta izin dari pemegang hak cipta jika ingin menyewakan software.

- Menjual kembali software orisinal. Lisensi software biasanya juga menyebutkan bahwa pembeli hanya membayar untuk mendapat hak menggunakan software tersebut. Penjualan kembali mungkin diizinkan jika dilakukan untuk tujuan pendidikan dan tindakan non-profit lainnya.

- Pembajakan internet / Internet piracy. Pelanggaran ini terjadi ketika Operator Sistem menyebarluaskan suatu materi yang dilindungi hak cipta pada bulletin board atau di internet sehingga dapat didownload secara bebas.

\section{Kesimpulan}

HAKI adalah pengakuan
hukum yang memungkinkan
pemegang hak (atas) kekayaan
intelektual tersebut mengatur
penggunaan gagasan-gagasan dan
ekspresi yang diciptakannya dalam
jangka waktu tertentu. Istilah
"kekayaan intelektual" mencerminkan
bahwa hal tersebut merupakan hasil
pikiran atau intelektualitas, dan bahwa
hak kekayaan intelektual dapat
dilindungi oleh hukum sebagaimana
bentuk hak milik lainnya.

\section{B. CONTENT}

Kekayaan intelektual adalah
kekayaan yang timbul dari kemampuan intelektual manusia yang dapat berupa karya di bidang teknologi, ilmu pengetahuan, seni dan sastra. Karya ini dihasilkan atas kemampuan intelektual melalui pemikiran, daya cipta dan rasa yang memerlukan curahan tenaga, waktu dan biaya untuk memperoleh "produk" baru dengan landasan kegiatan penelitian atau yang sejenis.

Secara singkat HAKI adalah hak yang muncul bagi hasil olah pikir otak yang menghasilkan suatu produk atau proses yang berguna bagi manusia .Objek yang diatur dalam HAKI adalah karya-karya yang lahir akibat kemampuan intelektual manusia.

Secara umum HAKI dibagi menjadi 2 (dua) bagian, yaitu:

\section{Hak Cipta (copyrights)}

Hak Cipta merupakan hak eksklusif bagi Pencipta atau Pemegang Hak Cipta untuk mengumumkan atau memperbanyak Ciptaannya, yang timbul secara otomatis setelah suatu 
ciptaan dilahirkan tanpa mengurangi pembatasan menurut peraturan perundang ᄀundangan yang berlaku.

Pencipta dan/atau Pemegang Hak Cipta atas karya sinematografi dan Program Komputer memiliki hak untuk memberikan izin atau melarang orang lain yang tanpa persetujuannya menyewakan Ciptaan tersebut untuk kepentingan yang bersifat komersial.

Ciptaan yang dilindungi oleh Undang-undang adalah Ciptaan dalam bidang ilmu pengetahuan, seni, dan sastra, yang mencakup: a. buku, Program Komputer, pamflet, perwajahan (lay out) karya tulis yang diterbitkan, dan semua hasil karya tulis lain;

b. ceramah, kuliah, pidato, dan Ciptaan lain yang sejenis dengan itu; c. alat peraga yang dibuat untuk kepentingan pendidikan dan ilmu pengetahuan;

d. lagu atau musik dengan atau tanpa teks;

e. drama atau drama musikal, tari, koreografi, pewayangan, dan pantomim;

f. seni rupa dalam segala bentuk seperti seni lukis, gambar, seni ukir, seni kaligrafi, seni pahat, seni patung, kolase, dan seni terapan; g.arsitektur;

hpeta

i.senibatik;

j.photografi

k.sinematografi

1. terjemahan, tafsir, saduran, bunga rampai, database, dan karya lain dari hasil pengaliwujudan.

Pemegang Hak Cipta berhak memberikan Lisensi kepada pihak lain berdasarkan surat perjanjian lisensi. Pelaksanaan perjanjian lisensi tersebut disertai dengan kewajiban pemberian royalti kepada Pemegang Hak Cipta oleh penerima Lisensi. Jumlah royalti yang wajib dibayarkan kepada Pemegang Hak Cipta oleh penerima Lisensi adalah berdasarkan kesepakatan kedua belah pihak dengan berpedoman kepada kesepakatan organisasi profesi.

\section{CONCLUSION}

Kekayaan intelektual adalah
kekayaan yang timbul dari kemampuan intelektual manusia yang dapat berupa karya di bidang teknologi, ilmu pengetahuan, seni dan sastra. Karya ini dihasilkan atas kemampuan intelektual melalui pemikiran, daya cipta dan rasa yang memerlukan curahan tenaga, waktu dan biaya untuk memperoleh "produk" baru dengan landasan kegiatan penelitian atau yang sejenis.

Secara singkat HAKI adalah hak yang muncul bagi hasil olah pikir otak yang menghasilkan suatu produk atau proses yang berguna bagi manusia .Objek yang diatur dalam HAKI adalah karya-karya yang lahir akibat kemampuan intelektual manusia.

Secara umum HAKI dibagi menjadi 2 (dua) bagian, yaitu:

\section{Hak Cipta (copyrights)}

Hak Cipta merupakan hak eksklusif bagi Pencipta atau Pemegang Hak Cipta untuk mengumumkan atau memperbanyak Ciptaannya, yang timbul secara otomatis setelah suatu ciptaan dilahirkan tanpa mengurangi pembatasan menurut peraturan perundang $\neg$ undangan yang berlaku.

Pencipta dan/atau Pemegang Hak Cipta atas karya sinematografi dan 
Program Komputer memiliki hak untuk memberikan izin atau melarang orang lain yang tanpa persetujuannya menyewakan Ciptaan tersebut untuk kepentingan yang bersifat komersial.

Ciptaan yang dilindungi oleh Undang-undang adalah Ciptaan dalam bidang ilmu pengetahuan, seni, dan sastra, yang mencakup: a. buku, Program Komputer, pamflet, perwajahan (lay out) karya tulis yang diterbitkan, dan semua hasil karya tulis lain;

b. ceramah, kuliah, pidato, dan Ciptaan lain yang sejenis dengan itu; c. alat peraga yang dibuat untuk kepentingan pendidikan dan ilmu pengetahuan;

d. lagu atau musik dengan atau tanpa teks;

e. drama atau drama musikal, tari, koreografi, pewayangan, dan pantomim;

f. seni rupa dalam segala bentuk seperti seni lukis, gambar, seni ukir, seni kaligrafi, seni pahat, seni patung, kolase, dan seni terapan; g.arsitektur;

hpeta

i.senibatik;

j.photografi

k.sinematografi

1. terjemahan, tafsir, saduran, bunga rampai, database, dan karya lain dari hasil pengaliwujudan.

Pemegang Hak Cipta berhak memberikan Lisensi kepada pihak lain berdasarkan surat perjanjian lisensi. Pelaksanaan perjanjian lisensi tersebut disertai dengan kewajiban pemberian royalti kepada Pemegang Hak Cipta oleh penerima Lisensi. Jumlah royalti yang wajib dibayarkan kepada Pemegang Hak Cipta oleh penerima Lisensi adalah berdasarkan kesepakatan kedua belah pihak dengan berpedoman kepada kesepakatan organisasi profesi.

\section{DISCUSSION}

Kekayaan intelektual adalah
kekayaan yang timbul dari kemampuan intelektual manusia yang dapat berupa karya di bidang teknologi, ilmu pengetahuan, seni dan sastra. Karya ini dihasilkan atas kemampuan intelektual melalui pemikiran, daya cipta dan rasa yang memerlukan curahan tenaga, waktu dan biaya untuk memperoleh "produk" baru dengan landasan kegiatan penelitian atau yang sejenis.

Secara singkat HAKI adalah hak yang muncul bagi hasil olah pikir otak yang menghasilkan suatu produk atau proses yang berguna bagi manusia .Objek yang diatur dalam HAKI adalah karya-karya yang lahir akibat kemampuan intelektual manusia.

Secara umum HAKI dibagi menjadi 2 (dua) bagian, yaitu:

\section{Hak Cipta (copyrights)}

Hak Cipta merupakan hak eksklusif bagi Pencipta atau Pemegang Hak Cipta untuk mengumumkan atau memperbanyak Ciptaannya, yang timbul secara otomatis setelah suatu ciptaan dilahirkan tanpa mengurangi pembatasan menurut peraturan perundang ᄀundangan yang berlaku.

Pencipta dan/atau Pemegang Hak Cipta atas karya sinematografi dan Program Komputer memiliki hak untuk memberikan izin atau melarang orang lain yang tanpa persetujuannya menyewakan Ciptaan tersebut untuk kepentingan yang bersifat komersial. 
Ciptaan yang dilindungi oleh Undang-undang adalah Ciptaan dalam bidang ilmu pengetahuan, seni, dan sastra, yang mencakup: a. buku, Program Komputer, pamflet, perwajahan (lay out) karya tulis yang diterbitkan, dan semua hasil karya tulis lain;

b. ceramah, kuliah, pidato, dan Ciptaan lain yang sejenis dengan itu; c. alat peraga yang dibuat untuk kepentingan pendidikan dan ilmu pengetahuan;

d. lagu atau musik dengan atau tanpa teks;

e. drama atau drama musikal, tari, koreografi, pewayangan, dan pantomim;

f. seni rupa dalam segala bentuk seperti seni lukis, gambar, seni ukir, seni kaligrafi, seni pahat, seni patung, kolase, dan seni terapan; g.arsitektur;

hpeta

i.senibatik;

j.photografi

k.sinematografi

1. terjemahan, tafsir, saduran, bunga rampai, database, dan karya lain dari hasil pengaliwujudan.

Pemegang Hak Cipta berhak memberikan Lisensi kepada pihak lain berdasarkan surat perjanjian lisensi. Pelaksanaan perjanjian lisensi tersebut disertai dengan kewajiban pemberian royalti kepada Pemegang Hak Cipta oleh penerima Lisensi. Jumlah royalti yang wajib dibayarkan kepada Pemegang Hak Cipta oleh penerima Lisensi adalah berdasarkan kesepakatan kedua belah pihak dengan berpedoman kepada kesepakatan organisasi profesi.

\section{PELANGGARAN HAK CIPTA :}

dapat dikenakan hukuman sesuai dengan pasal 72 Undang-undang :

(1) Barangsiapa dengan sengaja dan tanpa hak melakukan perbuatan sebagaimana dimaksud dalam Pasal 2 ayat (1) atau Pasal 49 ayat (1) dan ayat (2) dipidana dengan pidana penjara masing-masing paling singkat 1 (satu) bulan dan/atau denda paling sedikit Rp 1.000.000,00 (satu juta rupiah), atau pidana penjara paling lama 7 (tujuh) tahun dan/atau denda paling banyak Rp 5.000.000.000,00 (lima miliar rupiah).

(2) Barangsiapa dengan sengaja menyiarkan, memamerkan, mengedarkan, atau menjual kepada umum suatu Ciptaan atau barang hasil pelanggaran Hak Cipta atau Hak Terkait sebagaimana dimaksud pada ayat (1) dipidana dengan pidana penjara paling lama 5 (lima) tahun dan/atau denda paling banyak $\mathrm{Rp}$ 500.000.000,00 (lima ratus juta rupiah).

(3) Barangsiapa dengan sengaja dan tanpa hak memperbanyak penggunaan untuk kepentingan komersial suatu Program Komputer dipidana dengan pidana penjara paling lama 5 (lima) tahun dan/atau denda paling banyak Rp 500.000.000,00 (lima ratus juta rupiah).

(4) Barangsiapa dengan sengaja melanggar Pasal 17 dipidana dengan pidana penjara paling lama 5 (lima) tahun dan/atau denda paling banyak Rp 1.000.000.000,00 (satu miliar rupiah).

(5) Barangsiapa dengan sengaja melanggar Pasal 19, Pasal 20, atau Pasal 49 ayat (3) dipidana dengan pidana penjara paling lama 2 (dua) tahun dan/atau denda paling banyak Rp 150.000.000,00 (seratus lima puluh 
juta rupiah).

(6) Barangsiapa dengan sengaja dan tanpa hak melanggar Pasal 24 atau Pasal 55 dipidana dengan pidana penjara paling lama 2 (dua) tahun dan/atau denda paling banyak $\mathrm{Rp}$ 150.000.000,00 (seratus lima puluh juta rupiah). (7) Barangsiapa dengan sengaja dan tanpa hak melanggar Pasal 25 dipidana dengan pidana penjara paling lama 2 (dua) tahun dan/atau denda paling banyak Rp 150.000.000,00 (seratus lima puluh juta rupiah). (8) Barangsiapa dengan sengaja dan tanpa hak melanggar Pasal 27 dipidana dengan pidana penjara paling lama 2 (dua) tahun dan/atau denda paling banyak Rp 150.000.000,00 (seratus lima puluh juta rupiah). (9) Barangsiapa dengan sengaja melanggar Pasal 28 dipidana dengan pidana penjara paling lama 5 (lima) tahun dan/atau denda paling banyak Rp 1.500.000.000,00 (satu miliar lima ratus juta rupiah).

\section{E. REFERENCE}

[1] O. M. Febriani and A. S. Putra, "Sistem Informasi Monitoring Inventori Barang Pada Balai Riset Standardisasi Industri Bandar Lampung," J. Inform., vol. 13, no. 1, pp. 90-98, 2014.

[2] A. S. Putra, "Paperplain: Execution Fundamental Create Application With Borland Delphi 7.0 University Of Mitra Indonesia," 2018.

[3] A. S. Putra, "2018 Artikel Struktur Data, Audit Dan Jaringan Komputer,” 2018.
[4] A. S. Putra, "ALIAS MANAGER USED IN DATABASE DESKTOP STUDI CASE DB DEMOS."

[5] A. S. Putra, "COMPREHENSIVE SET OF PROFESSIONAL FOR DISTRIBUTE COMPUTING."

[6] A. S. Putra, "DATA ORIENTED RECOGNITION IN BORLAND DELPHI 7.0."

[7] A. S. Putra, "EMBARCADERO DELPHI XE 2 IN GPUPOWERED FIREMONKEY APPLICATION."

[8] A. S. Putra, "HAK ATAS KEKAYAAN INTELEKTUAL DALAM DUNIA TEKNOLOGY BERBASIS REVOLUSI INDUSTRI 4.0."

[9] A. S. Putra, "IMPLEMENTASI PERATURAN

PERUNDANGAN UU. NO 31

TAHUN 2000 TENTANG

DESAIN INDUSTRI

BERBASIS INFORMATION TECHNOLOGY."

[10] A. S. Putra, "IMPLEMENTATION OF PARADOX DBASE."

[11] A. S. Putra, "IMPLEMENTATION OF TRADE SECRET CASE STUDY SAMSUNG MOBILE PHONE."

[12] A. S. Putra, "IMPLEMENTATION

PATENT FOR APPLICATION WEB BASED CASE STUDI WWW. PUBLIKLAMPUNG. COM." 
[14] A. S. Putra, "MANUAL REPORT \& INTEGRATED DEVELOPMENT

ENVIRONMENT BORLAND DELPHI 7.0."

[15] A. S. Putra, "PATENT AS RELEVAN SUPPORT RESEARCH."

[16] A. S. Putra, "PATENT FOR RESEARCH STUDY CASE OF APPLE. Inc."

[17] A. S. Putra, "PATENT PROTECTION FOR APPLICATION INVENT."

[18] A. S. Putra, "QUICK REPORT IN PROPERTY PROGRAMMING."

[19] A. S. Putra, "REVIEW CIRCUIT LAYOUT COMPONENT

REQUIREMENT ON ASUS NOTEBOOK."

[20] A. S. Putra, "REVIEW TRADEMARK PATENT FOR INDUSTRIAL TECHNOLOGY BASED 4.0."

[21] A. S. Putra, "TOOLBAR COMPONENT PALLETTE IN OBJECT ORIENTED PROGRAMMING."

[22] A. S. Putra, "WORKING DIRECTORY SET FOR PARADOX 7."

[23] A. S. Putra, "ZQUERY CONNECTION IMPLEMENTED PROGRAMMING STUDI CASE PT. BANK BCA Tbk."

[24] A. S. Putra, D. R. Aryanti, and I. Hartati, "Metode SAW (Simple Additive Weighting) sebagai Sistem Pendukung Keputusan Guru Berprestasi (Studi Kasus: SMK Global Surya)," in Prosiding Seminar
Nasional Darmajaya, 2018, vol. 1, no. 1, pp. 85-97.

[25] A. S. Putra and O. M. Febriani, "Knowledge Management Online Application in PDAM Lampung Province," in Prosiding International conference on Information Technology and Business (ICITB), 2018, pp. 181-187.

[26] A. S. Putra, O. M. Febriani, and B. Bachry, "Implementasi Genetic Fuzzy System Untuk Mengidentifikasi Hasil Curian Kendaraan Bermotor Di Polda Lampung," SIMADA (Jurnal Sist. Inf. dan Manaj. Basis Data), vol. 1, no. 1, pp. 21-30, 2018.

[27] A. S. Putra, H. Sukri, and K. Zuhri, "Sistem Monitoring Realtime Jaringan Irigasi Desa (JIDES) Dengan Konsep Jaringan Sensor Nirkabel," IJEIS (Indonesian J. Electron. Instrum. Syst., vol. 8, no. 2, pp. 221-232.

[28] D. P. Sari, O. M. Febriani, and A. S. Putra, "Perancangan Sistem Informasi SDM Berprestasi pada SD Global Surya," in Prosiding Seminar Nasional Darmajaya, 2018, vol. 1, no. 1, pp. 289-294. 